\title{
Striking Promotion of the In Vitro Myeloma Monoclonal Immunoglobulin Aggregation by Ankaferd Hemostat
}

\author{
Murat ALBAYRAK ${ }^{1}$, Salih AKSU² ${ }^{2}$ Harika CELEBI ${ }^{1}$, Aynur ALBAYRAK ${ }^{3}$, Zeynep GINIS $^{4}$, \\ Server YAGCI ${ }^{5}$, Ozlem S. BALCIK ${ }^{6}$, Osman YOKUS ${ }^{7}$, Ibrahim C. HAZNEDAROGLU ${ }^{2}$ \\ ${ }^{1}$ Diskapi Training and Research Hospital, Department of Hematology, Ankara \\ ${ }^{2}$ Hacettepe University Medical School, Department of Internal Medicine and Hematology, Ankara \\ ${ }^{3}$ Diskapi Training and Research Hospital, Department of Pathology, Ankara \\ ${ }^{4}$ Diskapi Training and Research Hospital, Department of Clinical Biochemistry, Ankara \\ ${ }^{5}$ Kecioren Training and Research Hospital, Department of Microbiology and Clinical Microbiology, Ankara \\ ${ }^{6}$ Fatih University Medical School, Department of Internal Medicine and Hematology, Ankara \\ ${ }^{7}$ Okmeydanı Training and Research Hospital, Department of Hematology, Istanbul, TURKEY
}

\begin{abstract}
Ankaferd Blood Stopper (ABS) is a novel topical hemostatic agent. ABS-induced formation of the protein network with vital erythroid aggregation covers the entire physiological hemostatic process. ABS has pleiotropic cellular, proteomic, transcriptomic, and metabolomic effects. ABS also affects the expression of important hemostatic molecules namely PAR-1, EPCR and PAI-1. The aim of this study was to detect the macroscopic, biochemical, and cytopathological effects of ABS on myeloma monoclonal immunoglobulin (M-protein). Based on our results, the addition of ABS into the serum of both multiple myeloma (MM) and control groups resulted in significantly decrements in the level of total protein, albumin, IgG, IgA and IgM. Furthermore, the decrements in the MM patients were more pronounced than in the healthy control subjects. ABS has a potential role in decreasing of serum proteins and monoclonal M- proteins. Moreover, the declining in the neoplastic monoclonal M-protein was more prominent. We hypothesized that ABS could be used as an "agglutination-controlling factor" for myeloma monoclonal proteins and the protein-aggregating effects of ABS may be helpful for expressing the regulatory molecules promoting or preventing the myeloma protein aggregation.
\end{abstract}

Keywords: Ankaferd Blood Stopper (ABS), Multiple myeloma, Paraprotein, M-protein, Protein aggregasyon, Erythroid aggregation, Hemostasis

\section{ÖZET}

Ankaferd Hemostat ile İn Vitro Myelom Monoklonal İmmünglobulin Agregasyonunun Belirgin Artışı

Ankaferd Blood Stopper (ABS) yeni bir topikal hemostatic ajandır. ABS tarafından indüklenen protein ağı oluşumu hayati eritroid agregasyonu ile birlikte tüm fizyolojik hemostatik süreci kapsar. ABS hücresel pleiotropik, proteomik, transkriptomik ve metabolik etkilere sahiptir. ABS aynı zamanda PAR-1, EPCR ve PAl-1 gibi önemli hemostatik moleküllerin ekspresyonunu da etkiler. Bu çallşmanın amacl; ABS'nin miyelom monoklonal immünoglobulini (M-protein) üzerindeki makroskopik, biyokimyasal ve sitopatolojik etkilerini saptamaktı. Sonuçlarımıza göre, hem multiple myelom (MM) hem de kontrol gruplarının serumlarına ABS ilavesi total protein, albumin, IgG, IgA ve IgM seviyelerinde belirgin bir azalmayla sonuçlandı. Ek olarak, MM hastalarında görülen azalma sağlikIl kontrol grubundakilerden daha belirgindi. ABS serum proteinlerinin ve monoklonal M-proteinlerinin azalmasında potansiyel bir role sahiptir. Ayrıca neoplastik monoklonal M-proteinlerindeki azalma daha da belirgindi. Hipotezimize göre, ABS miyelom monoklonal proteini için "agglütinasyonu control eden faktör"'olarak kullanılabilir ve ABS'nin proteinleri aglütine edici etkisi, miyelom protein agregasyonunu önleyen veya arttıran düzenleyici moleküllerin ekspresyonunda yardımcı olabilir.

Anahtar Kelimeler: Ankaferd kan durdurucu, Multipl miyelom, Paraprotein, M-protein, Protein agregasyonu,

Eritroid agregasyonu, Hemostaz 


\section{INTRODUCTION}

Ankaferd Blood Stopper (ABS), a novel topical hemostatic agent, has been approved in Turkey for clinical hemorrhages, when the conventional control of bleeding by ligature and/or conventional hemostatic measures is ineffective. ${ }^{1-3} \mathrm{ABS}$ is clinically effective in bleeding individuals with normal hemostatic parameters and in patients with deficient primary hemostasis and/or secondary hemostasis..$^{4-14}$ ABS-induced formation of the protein network with vital erythroid aggregation covers the entire physiological hemostatic process. There are distinct important mediator components of the ABS-induced cellular hemostatic network. Vital erythroid aggregation takes place with the spectrin, ankrin and actin receptors on the surface of red blood cells. Those proteins and the required ATP bioenergy are included within the ABS protein library. ${ }^{2,315}$ Ankaferd also up-regulates GATA/FOG transcription system affecting erythroid functions. Urotensin II is also an essential component of Ankaferd and represents the link between injured vascular endothelium, adhesive proteins, and active erythroid cells. ${ }^{15,16}$ Those concepts have been developed via MALDI-TOF proteomic molecular analyses, cytometric arrays, transciption analysis, and SEM ultrastructural examinations as well as numerous investigations interacting with in vitro and in vivo research settings. . $^{-3,15-20}$

ABS has many cellular effects. ${ }^{1,21-23}$ ABS has been shown to affect renal tubular apoptosis based on the level of hemorrhage. ${ }^{22}$ When the bleeding associated with the surgery of partial nephrectomy is mild or moderate, ABS can initially increase renal tubular apoptosis. On the contrary; during the increased amount of massive bleeding from the kidney tissue, ABS decreases apoptosis in renal tubular cells..$^{22}$ Therefore, ABS modulates the cellular apoptotic responses to hemorrhagic stress as well as its hemostatic hemodynamic activity. The finding of ABS-induced thrombin receptor down-regulation gives an additional clue on the possible mechanism of ABS associated apoptosis modulation at the tissue level. ${ }^{20}$ Preliminary findings focusing on in vitro anti-neoplastic effects $^{24,25}$ of ABS also prompt to begin for searching the ABS effects at the cellular level in health and in neoplastic diseases.

ABS has many effects on proteins at the tissue and

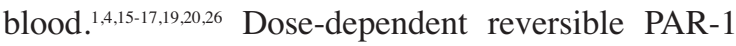

down-regulation is mediated by ABS. ABS induced sustained PAR-1 down-regulation in the presence of lipopolysaccharides (LPS). ${ }^{20}$ Those findings are compatible with other investigations focusing on the endothelial hemostatic molecules, EPCR and PAI-1.19 ABS had dual diverse dynamic reversible actions on EPCR and PAI-1 inside vascular endothelial cells also in the model of HUVEC. Sudden anti-hemorrhagic efficacy of ABS via immediately enhanced expression of pro-hemostatic PAI-1 and down-regulated anti-coagulant EPCR upon the exposure of ABS were shown. ${ }^{19}$ Those findings suggested that ABS may act as a topical biological response modifier.

The aim of this study is to detect the macroscopic, biochemical, and cytopathological effects of ABS on myeloma monoclonal immunoglobulin (M-protein). M-proteins are secreted from the neoplastic plasma cells and are responsible for a wide variety of the clinical spectrum of multiple myeloma. ${ }^{27-29}$ We intended to analyze the ABS-effect on the neoplastic M-protein in comparison to normal serum proteins. The clinicopathological perspectives with the study hypothesis were that ABS could be used as an 'agglutination-controlling factor' for myeloma monoclonal proteins and the protein-aggregating effects of $\mathrm{ABS}$ may be helpful for expressing the regulatory molecules promoting or preventing the myeloma protein aggregation.

\section{MATERIALS AND METHODS}

Study Design: Ten patients with MM (male/female: $5 / 5$ ), and 5 healthy adults (male/female: $3 / 2$ ) as controls were enrolled into the research. The newly diagnosed or therapy naive MM patients were included in the study. The diagnosis of MM was reached by International diagnostic criteria. Five of the patients were IgG subtype, and the other five were IgA subtype of MM. The patients with co-morbid disease were excluded from the study. Written informed consents were obtained from all the participants.

Collection of the Serum: Five milliliters $(\mathrm{ml})$ of venous blood was taken from each of the cases. All of the samples were centrifugated at $3000 \mathrm{G}$ for $10 \mathrm{mi}-$ nutes to collect two $\mathrm{ml}$ serum sample. Subsequently, the sera were stored at $-20^{\circ} \mathrm{C}$ until assayed.

ABS, Ankaferd Blood Stopper $\AA^{\circledR}$ The samples of ABS (Ankaferd Blood Stopper ${ }^{\circledR}$, patent number 


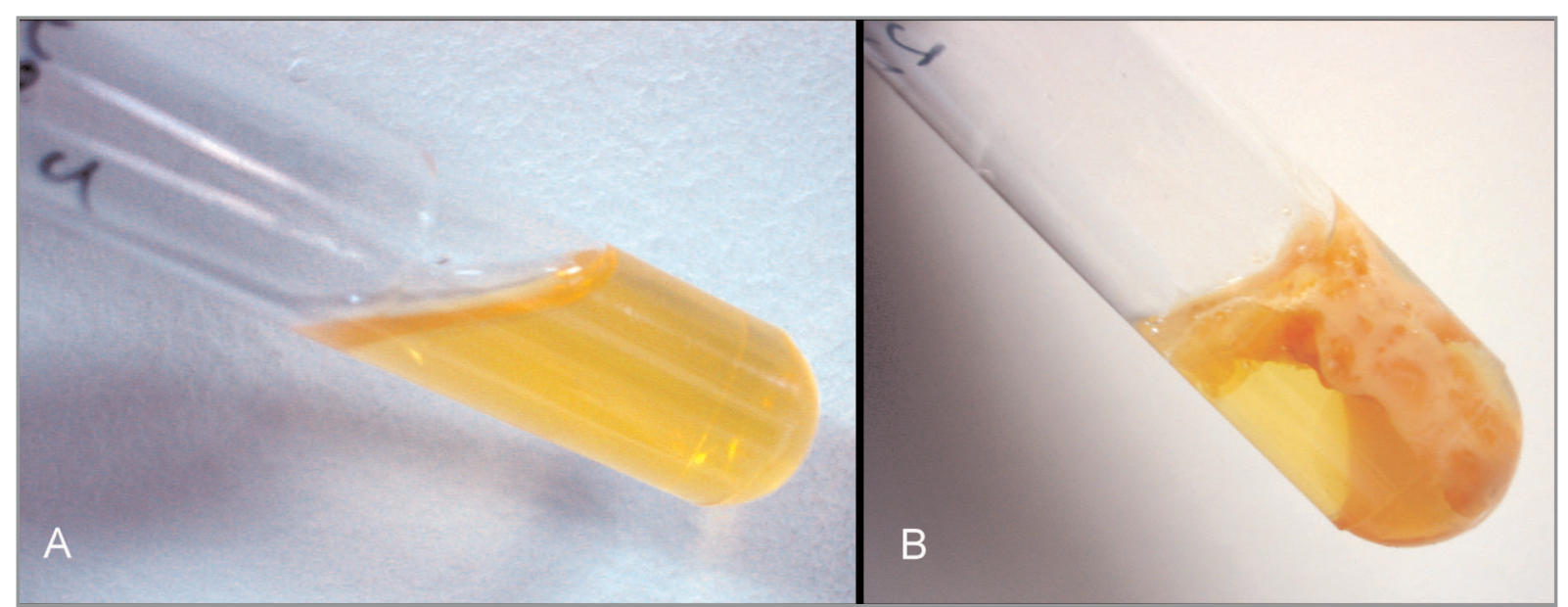

Image 1A. The macroscopic image of the serum before the addition of $A B S$

2007-0-114485; Ankaferd Drug Inc. Istanbul, Turkey) used in this study had the lot number 712001 (one vial of $100 \mathrm{ml}$ ).

Cytopathological Examination: The patients' serum samples were centrifugated at $2000 \mathrm{G}$ for $10 \mathrm{mi}-$ nutes before and after adding of ABS. Cytological smear were prepared from the residue particles after the centrifugation process. The preparations were fixed in $95 \%$ ethanol and stained with Papanicolaou stain. Light microscope was used for cytological evaluations.

Biochemical Analyses: The sera of the patients and controls were taken from storage and melted. Analyzing of the levels of total protein, albumin (Siemens Advia 2400), IgG, IgM, IgA (IMMAGE Immunochemistry Systems assay, Beckman Coulter, USA) in serum and protein electrophoresis (Sebia, cellulose acetate electrophoresis) were done before and after adding of ABS. The sera were applied on to the cellulose acetate plaques which wet via $5 \mu \mathrm{L}$ micropipettes with "twin wire" applicator. The cellulose acetate membranes were run at 180 volts $30 \mathrm{~mA}$ for 15 min. stained by Pancoas $S$ and became transparent with washing by densitometer.

Statistical Analyses: The data were expressed as median \pm SD. Mann Whitney U and Kruskal Wallis tests were used to compare the groups. SPSS package 13.0 was used for the statistical analysis. A p-value of $<0.05$ was considered as statistically significant.
Image 1B: The macroscopic image of the serum after the addition of $A B S$

\section{RESULTS}

The serum samples of ten newly diagnosed MM patients and five cases of the control group were analyzed in the study. Five out of ten MM patients were $\mathrm{IgG}$, and the other five were $\operatorname{IgA}$ subtype of MM. Before adding of ABS, the serum sample were all clear (Image 1A), wheras in a few seconds after adding of $\mathrm{ABS}$, the nature of serum were totally changed, jelly solidifications were determined (Image 1B). According to the light microscopic examination of the cytological smear, there weren't any pathological findings before adding of ABS (Image 2A), however after the adding of ABS, clusters of proteineous material were determined (Image 2B).

Analyzing of the levels of total protein, albumin, $\mathrm{IgG}, \operatorname{IgM}, \operatorname{IgA}$ in the serum and protein electrophoresis were performed before and after the addition of ABS. The results of the both groups were depicted in Table 1. Significant decrements in the level of total protein, albumin, $\operatorname{IgG}$ and $\operatorname{IgA}$ in patient group were determined after the addtion of ABS $(\mathrm{p}<0.005)$. There was also decrements in the level of $\operatorname{IgM}$ after the addition of ABS, however it was statistically indifferent $(\mathrm{p}<0.241)$. The decrements in the level of total protein, albumin, IgG, IgA and IgM determined in the control group after the addition of ABS were also significantly different $(\mathrm{p}<0.043)$. The decrements in the level of total protein, $\operatorname{IgG}$ and $\operatorname{IgA}$ in the MM group were more pronounced than in the control group $(\mathrm{p}<0.01, \mathrm{p}<0.008, \mathrm{p}<0.009$, respectively). Se- 


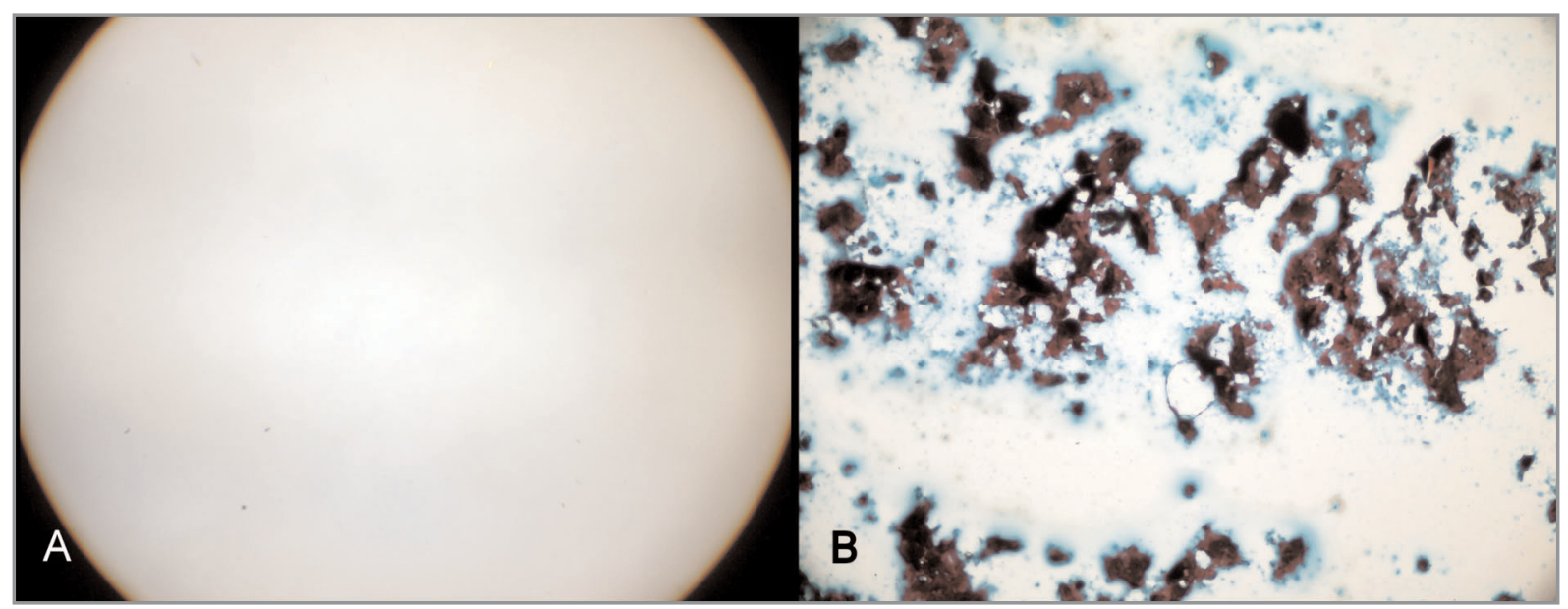

Image 2A. The appearance of serum by light microscope before the addition of ABS (Papanicolau stain, X100)

rum protein electrophoresis in both groups could not be done after the addition of ABS because of the low protein content in the "ABS exposed-serum". The comparison of total protein, $\operatorname{IgG}$ and $\operatorname{IgA}$ levels in the $\mathrm{MM}$ and control groups after the addition of ABS were depicted in Figures 1-3.

In summary, the addition of ABS into the serum of both $\mathrm{MM}$ and control groups resulted in significantly
Image 2B. The appearance of serum by light microscope after the addition of ABS (Papanicolau stain, X100)

decrements in the level of total protein, albumin, $\operatorname{IgG}, \operatorname{Ig} \mathrm{A}$ and $\operatorname{IgM}$. Furthermore, the decrements in the MM patients were more pronounced than in the healthy control subjects. ABS has a potential role in decreasing of serum proteins and monoclonal Mproteins. Moreover, the declining in the neoplastic monoclonal M-protein was more prominent.

Table 1. The comparisons of the biochemical parameters before and after the addition of ABS in the serum of patients with multiple myeloma (MM) and the healthy control group

\begin{tabular}{|c|c|c|c|}
\hline & Before the addition of ABS & After the addition of ABS & $\mathbf{P}$ \\
\hline MM PATIENTS $(n=10)$ & MM PATIENT GROUP & MM PATIENT GROUP & \\
\hline Total Protein (g/dl) & $8,50 \pm 1.34(6.60-9.80)$ & $0.35 \pm 1.44(0.00-4.80)$ & 0.005 \\
\hline Albumin $(\mathrm{g} / \mathrm{dl})$ & $2.95 \pm 0.48(2.40-3.60)$ & $0.20 \pm 4.50(0.10-1.70)$ & 0.005 \\
\hline $\operatorname{lgG}(\mathrm{mg} / \mathrm{dl})$ & $1675.50 \pm 158,95(244,00-6620,00)$ & $57.90 \pm 585,10(33,30-1840.00)$ & 0.005 \\
\hline $\operatorname{lgA}(\mathrm{mg} / \mathrm{dl})$ & $529.60 \pm 3050.25(18.10-7140.00)$ & $6.67 \pm 661.93(6.67-2100.00)$ & 0.005 \\
\hline $\operatorname{lgM}(\mathrm{mg} / \mathrm{dl})$ & $25.40 \pm 29.39(4.17-103.00)$ & $8.15 \pm 17.44(4.17-56.90)$ & 0.241 \\
\hline CONTROL $(n=5)$ & CONTROL GROUP & CONTROL GROUP & \\
\hline Total Protein & $7.10 \pm 1.34(6.60-9.80)$ & $3.50 \pm 1.24(1.30-4.00)$ & 0.043 \\
\hline Albumin & $4.50 \pm 0.70(4.00-5.80)$ & $2.20 \pm 0.67(1.00-2.60)$ & 0.043 \\
\hline $\operatorname{lgG}(\mathrm{mg} / \mathrm{dl})$ & $1140.00 \pm 156.60(928.00-1350.00)$ & $662.00 \pm 158.95$ ( 399.00-741.99) & 0.043 \\
\hline $\operatorname{lgA}(\mathrm{mg} / \mathrm{dl})$ & $144.00 \pm 72.76(114.00-290.00)$ & $80.60 \pm 49.68(152.00-110)$ & 0.043 \\
\hline $\operatorname{lgM}(\mathrm{mg} / \mathrm{dl})$ & $89.60 \pm 61.35(70.10-217.00)$ & $43.90 \pm 44.43(20.60-133.00)$ & 0.043 \\
\hline
\end{tabular}




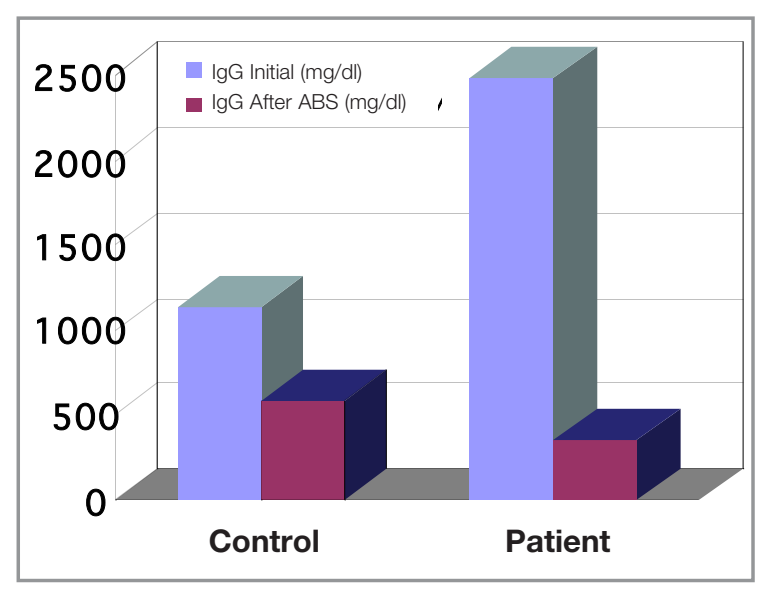

Figure 1. The comparisons of declining lgG level before and after the addition of ABS in the sera of patients with Multiple myeloma and control group.

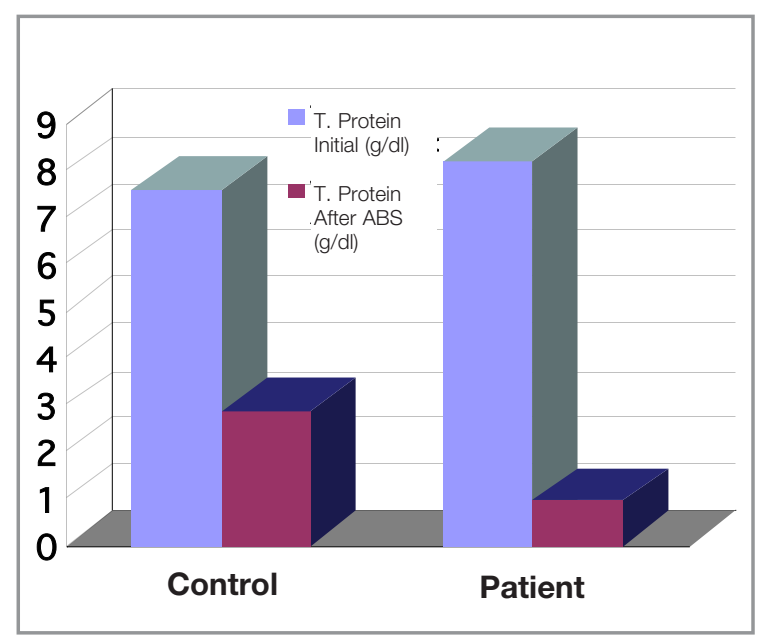

Figure 3. The comparisons of declining total protein level before and after the addition of ABS in the sera of patients with multiple myeloma and control group.

\section{DISCUSSION}

In this study, we have detected striking macroscopic, biochemical, and cytopathological effects of ABS on myeloma monoclonal immunoglobulin (M-protein). ABS produced a very rapid (less than one second) visible gel matrix protein network inside the human serum with or without myeloma (Images 1 and 2). Comparable findings have previously been observed in pancreatic fluid with $\mathrm{ABS} .{ }^{26}$ Adding $\mathrm{ABS}$ on the myeloma serum fluid not only lead to the aggregates

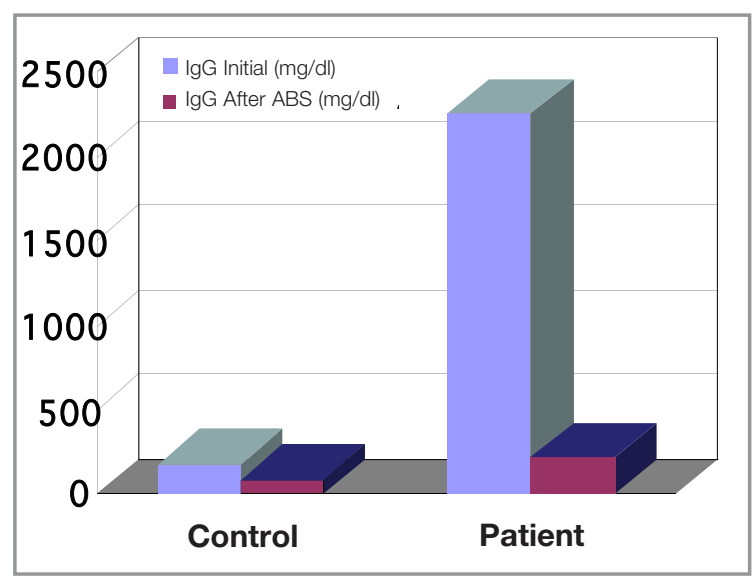

Figure 2. The comparisons of declining IgA level before and after the addition of ABS in the sera of patients with Multiple myeloma and control group.

of protein network resulting in a solid layer like a frozen gel but also produced important in vitro biochemical alterations (Table 1). Serum total protein, albumin, $\operatorname{IgG}, \operatorname{IgM}$ and IgA levels were decreased via ABS significantly in patients with multiple myeloma in comparison to the healthy controls (Figures 1-3). Neoplastic M-protein also decreased as detected by biochemical investigations and protein electrophoresis. Those findings indicate that ABS shall be accepted as an "agglutination-controlling factor" for myeloma monoclonal proteins in vitro.

Myeloma monoclonal proteins are secreted from the neoplastic plasma cells and are responsible for the expanding clinical spectrum of multiple myeloma. ${ }^{27-}$ ${ }^{29} \mathrm{M}$-protein could have a function as a receptor or ligand by being expressed on the myeloma cell surface. M-protein may act as the secretory factor that can regulate cellular conditions such as growth and differentiation in disease genesis. Based on our in vitro M-protein aggregating effects of ABS in this study, future in vivo experimental studies should focus on the hypothesis that protein-aggregating effects of ABS may be helpful for expressing the regulatory molecules promoting or preventing the myeloma protein aggregation.

Dose-dependent reversible PAR-1 down-regulation is mediated by ABS inside the human umbilical vein endothelial cells. ABS induced sustained PAR-1 down-regulation in the presence of LPS. Those findings are compatible with our previous investigation 
focusing on the endothelial hemostatic molecules, EPCR and PAI-1. ${ }^{19}$ ABS had dual diverse dynamic reversible actions on EPCR and PAI-1 inside vascular endothelial cells also in the model of HUVEC. Sudden anti-hemorrhagic efficacy of ABS via immediate enhanced expression of pro-hemostatic PAI-1 and down-regulated anti-coagulant EPCR upon the exposure of ABS.$^{19}$ Hemostatic function of PAR-1 is mainly prothrombotic. Significant PAR-1 down-regulation mediated by $\mathrm{ABS}$ indicated that $\mathrm{ABS}$ has balanced effects on global hemostasis..$^{20}$ Coagulation proteins, namely factor II, V, VII, VIII, IX, X, XI, and XIII were not affected in vitro individually by ABS. ${ }^{17}$ Likewise, prothrombin time (PT) and activated partial thromboplastin time (aPTT) were normal via the application of ABS. However, prolonged thrombin time (TT) was evident. ${ }^{17}$ Since PAR-1 is the most important thrombin receptor, depression of PAR-1 with ABS, could explain the prolonged TT due to ABS. The disease course of multiple myeloma also affects TT via anti-thrombin antibodies and erythroid aggregation. Therefore, pharmacological actions of ABS and pathobiological behavior of myeloma cells share some mechanistic similarities; an association remains to be elucidated.

It has been suggested that ABS could act as a topical biological response modifier via demonstrating diverse actions of ABS in the presence of LPS. ${ }^{1920}$ "LPS challenge" refers to the process of exposing a biological environment to an LPS which may act as a toxin to test immunological and hemostatic responses. LPS application to HUVEC caused ABS-induced additional sustained significant down-regulations in the expressions of PAR- 1 mRNA..$^{20}$ Sustained significant PAR-1 down-regulation mediated by ABS in the presence of LPS seems to have a protective role against endothelial injury. Therefore, there are molecular links underlying ABS-pleiotropic cellular actions acting on anti-infective $\mathrm{e}^{30-32}$, wound healing $^{2,33-36}$, and apoptotic processes..$^{22,23}$ Since myeloma is located at the crossroads of cellular neoplastic development and M-protein secretion, the unique effects of ABS on distinct clonal paraproteins shall be investigated in future in vivo animal models mimicking plasma cell disorders. Our present study represent true basis for the design of such trials.

There are distinct important molecular components of the ABS-induced hemostatic network involving vascular endothelium, proteins, and blood cells. The concept of ABS-induced hemostatic network has been developed via MALDI-TOF proteomic molecular analyses, cytometric arrays, transciption analysis, and SEM ultrastructural examinations as well as numerous investigations interacting with in vitro and in vivo research settings..$^{1-3,15-20}$ Essential erythroid proteins (Ankrin recurrent and FYVE bundle containing protein 1, Spectrin alpha, Actin-depolimerisation factor, Actin-depolimerizing factor, LIM bundle and actine binding subunit 1 isoform a, LIM bundle and actine binding subunit 1 isoform $b$, NADP-dependent malic enzyme, NADH dehydrogenase (Ubiquinone) 1 alpha subcomplex, Mitochondrial NADP (+) dependent malic enzyme 3, Ribulose bisphosphatecarbocsilase large chain, Maturase K) and the required ATP bioenergy (ATP synthase, ATP synthase beta subunit, ATP synthase alpha subunit, ATP-binding protein $\mathrm{C} 12$, TP synthase $\mathrm{H}+$ transporter protein, ADF, Alpha-1,2-glycosyltransferase ALG10-A) are included in the protein library of ABS. ABS also upregulates GATA/FOG transcription system affecting erythroid functions and urotensin II. ${ }^{3,15,16}$ Further experimental search is needed to find out the molecules inside the ABS protein library leading to the ABS-induced aggregation of myeloma protein network.

PAR-1 modulates programmed cell death, apoptosis. Activation of PAR-1 can induce or paradoxically inhibit apoptosis in endothelial cells, fibroblasts, and tumor cells depending on the dosage of its physiological agonist thrombin..$^{20} \mathrm{ABS}$ has been shown to affect renal tubular apoptosis based on the level of hemorrhage in a previous study. ${ }^{22}$ When the bleeding associated with the surgery of partial nephrectomy is mild or moderate, ABS can initially increase renal tubular apoptosis. On the contrary; during the increased amount of massive bleeding from the kidney tissue, ABS decreases apoptosis in renal tubular cells. ${ }^{22}$ Therefore, ABS modulates the cellular apoptotic responses to hemorrhagic stress as well as its hemostatic hemodynamic activity. The finding of ABS-induced PAR-1 down-regulation gives an additional clue on the possible mechanism of ABS associated apoptosis modulation at the tissue level. ${ }^{20}$ PAR-1 is also involved in tumor responses. Preliminary findings focusing on in vitro anti-neoplastic effects ${ }^{24,25}$ of ABS also prompt to begin for searching the ABS effects at the cellular level. ABS has topically inhibited tumor angiogenesis. ${ }^{12}$ The hypothesis that ABS-induced aggregation of myeloma protein network can affect 
plasma cell growth should be investigated myeloma cell lines.

Ankaferd has superior hemostatic and wound-healing effects among other topical hemostatic agents. ${ }^{37}$ Its unique action is also present at the vascular tissue dynamics. ABS has vasoconstrictor effects at low concentrations $(5-10 \mu \mathrm{L})$, whereas it has vasodilator effects at high concentrations $(20-40-80 \mu \mathrm{L}) .^{38}$ Those actions are also evident at the tissue injury and bleeding due to major renal trauma. ${ }^{39} \mathrm{ABS}$-induced wound healing was also demonstrated in the dental tissues $^{40}$ and burns. ${ }^{41}$

Since ABS is currently being developed in basic and clinical grounds, those novel observations cast future studies focusing on the pleiotropic effects of this unique novel hemostatic agent. Future experimental trials should focus on the in vivo ABS effects on myeloma disease expression patterns. A pharmaceutical agent can be made based on the functional analyses using a secretory or membrane protein. Proteins suppressing or promoting the aggregation or deposition of M-proteins could intervene with in vitro diagnostic tests and in vivo disease management strategies. It could be possible to reveal a new ligand-receptor relationship by screening a membrane protein based on the binding activity with a known ligand or receptor. ABS protein library seems to be a starting point to begin designing those kinds of investigations.

\section{REFERENCES}

1. Beyazit $\mathrm{Y}$, Kurt M, Kekilli M, et al. Evaluation of hemostatic effects of Ankaferd as an alternative medicine. Altern Med Rev 15: 329-36, 2010.

2. Haznedaroglu BZ, Haznedaroglu IC, Walker SL, et al. Ultrastructural and morphological analyses of the in vitro and in vivo hemostatic effects of Ankaferd Blood Stopper. Clin Appl Thromb Hemost 16: 446-53, 2010.

3. Haznedaroglu IC. Molecular Basis of the Pleiotropic Effects of Ankaferd Blood Stopper. IUBMB Life (Suppl) 61: 290-290, 2009.

4. Ak G, Cakir O, Kazancioglu $\mathrm{HO}$, et al. The use of a new hemostatic agent: Ankaferd Blood Stopper in hemophiliacs. Haemophilia 16: 51-51, 2010.

5. Al B, Yildirim C, Cavdar M, et al. Effectiveness of Ankaferd blood stopper in the topical control of active bleeding due to cutaneous-subcutaneous incisions. Saudi Med J 30: 1520-1525, 2009.
6. Arslan S, Haznedaroglu IC, Oz B, et al. Endobronchial application of Ankaferd blood stopper to control profuse lung bleeding leading to hypoxemia and hemodynamic instability. Resp Med CME 2: 144-146, 2009.

7. Balcik OS, Koroglu M, Cipil H, et al. A Placebo-Controlled, Randomized, Double-Blinded, Cross-Over Phase I Clinical Study to Demonstrate Safety of Ankaferd Blood Stopper Topical Usage In Healthy Volunteers. Int J Lab Hem 32(Suppl 1):126-127, 2010.

8. Kurt M, Akdogan M, Onal IK, et al. Endoscopic topical application of Ankaferd Blood Stopper for neoplastic gastrointestinal bleeding: A retrospective analysis. Dig Liver Dis 42: 196-199, 2010.

9. Kurt M, Onal I, Akdogan M, et al. Ankaferd Blood Stopper for controlling gastrointestinal bleeding due to distinct benign lesions refractory to conventional antihemorrhagic measures. Can J Gastroenterol 24: 380384, 2010.

10. Meric Teker A, Korkut AY, Kahya V, et al. Prospective, randomized, controlled clinical trial of Ankaferd Blood Stopper in patients with acute anterior epistaxis. Eur Arch Otorhinolaryngol 267: 1377-1381, 2010.

11. Teker AM, Korkut AY, Gedikli O, et al. Prospective, controlled clinical trial of Ankaferd Blood Stopper in children undergoing tonsillectomy. Int J Pediatr Otorhinolaryngol 73: 1742-1745, 2009.

12. Turhan N, Kurt M, Shorbagi A, et al. Topical Ankaferd Blood Stopper administration to bleeding gastrointestinal carcinomas decreases tumor vascularization. Am J Gastroenterol 104: 2874-2877, 2009.

13. Yarali $N$, Oruc $M$, Bay $A$, et al. A new hemostatic agent-Ankaferd blood stopper: Management of gastrointestinal bleeding in an infant and other experiences in children. Pediatr Hematol Oncol 27: 592-596, 2010.

14. Zulfikar OB, Emiroglu HH, Kebudi R. Nasogastric application of topical Ankaferd Blood Stopper for bleeding from primary esophageal adenocarcinoma in a child with disseminated intravascular coagulation. Dig Liver Dis 43: 247-248, 2011.

15. Demiralp DO, Haznedaroglu IC, Akar N. Functional proteomic analysis of Ankaferd (R) Blood Stopper. Turk J Hematol 27: 70-77, 2010.

16. Yllmaz E, Gulec S, Haznedaroglu IC, Akar N. The effects of Ankaferd $\otimes$ Blood Stopper on transcription factors in HUVEC and erythrocyte protein profile. Turk J Hematol 28: 276-285, 2011.

17. Goker H, Haznedaroglu IC, Ercetin S, et al. Haemostatic actions of the folkloric medicinal plant extract Ankaferd Blood Stopper. J Int Med Res 36: 163-710, 2008.

18. Kandemir O, Buyukates M, Kandemir NO, et al. Demonstration of the histopathological and immunohistochemical effects of a novel hemostatic agent, Ankaferd Blood Stopper, on vascular tissue in a rat aortic bleeding model. J Cardiothorac Surg 5: 110, 2010.

19. Karabiyik A, Yılmaz E, Gulec S, et al. Dual diverse dynamic reversible actions of Ankaferd on EPCR and PAl-1 inside vascular endothelial cells with and without LPS. Turk J Hematol doi:10.5152/tjh.2011.41 
20. Karabiyik A, Gulec S, Yilmaz E, et al. Reversible Protease-Activated Receptor 1 Down-regulation Mediated By Ankaferd Blood Stopper Inducible With Lipopolysaccharides Inside The Human Umbilical Vein Endothelial Cells. Clin Appl Thromb Hemost 17: E165-170, 2011.

21. Comert M, Karakaya K, Barut F, et al. Does intraabdominal use of Ankaferd Blood Stopper cause increased intraperitoneal adhesions? Ulus Travma Acil Cerrahi Derg 16: 383-389, 2010.

22. Huri E, Haznedaroglu IC, Akgul T, et al. Biphasic effects of ankaferd blood stopper on renal tubular apoptosis in the rat partial nephrectomy model representing distinct levels of hemorrhage. Saudi Med J 30: 864868, 2010.

23. Odabas ME, Ertuk M, Cinar C, et al. Cytotoxicity of a new hemostatic agent on human pulp fibroblasts in vitro. Med Oral Patol Oral Cir Bucal 16: e584-587, 2011.

24. Goker H, Cetinkaya D, Kilic E, et al. Anti-cancer activity of ankaferd blood stopper on osteosarcom (SAOS-2) cell lines in vitro. In: Haznedaroglu IC, Goker H, Ozdemir O, Kosar A, Firat H, editor. Ankaferd: Scientific perspectives and basic-clinical data. Istanbul, Naviga Publications, 2008: 109.

25. Goker H, Kilic E, Cetinkaya D, et al. Anti-cancer activity of Ankaferd on human colon cancer (CACO-2) in vitro. In: Haznedaroglu IC, Goker H, Ozdemir O, et al., editors. Ankaferd: Scientific Perspectives and BasicClinical Data. Istanbul, Naviga Publications, 2008: 108.

26. Karaman K, Celep B, Bostanci EB, et al. Effects of Ankaferd Blood Stopper on pancreatic fluid: An in vitro study. ANZ J Surg 80: 946-947, 2010.

27. Serefhanoglu S, Haznedaroglu IC, Goker H, et al. Multiple bulky cutaneous plasmacytomas with CNS relapse without bone marrow involvement during the course of a lambda light chain myeloma. Onkologie 32: 662-664, 2009.

28. Serefhanoglu S, Sayinalp N, Haznedaroglu IC, et al. Extramedullary plasmacytomas of the thyroid and pericardium as initial presentation of multiple myeloma. Ann Hematol 87: 853-854, 2008.

29. Savas MC, Benekli M, Haznedaroglu IC, et al. Bulky plasmacytoma of the skull with intracranial involvement. Am J Hematol 54: 173, 1997.

30. Akkoc N, Akcelik M, Haznedaroglu IC, et al. In Vitro Anti-Bacterial Activities of Ankaferd Medicinal Plant Extract. Turkiye Klinikleri Tip Bilimleri Dergisi 29: 410415, 2009.

31. Saribas Z, Sener B, Haznedaroglu IC, et al. Antimicrobial activity of Ankaferd Blood StopperA (R) against nosocomial bacterial pathogens. Central European Journal of Medicine 5: 198-202, 2010.
32. Tasdelen FN, Tanriverdi CY, Coban AY, et al. Antimicrobial activity of plant extract Ankaferd Blood Stopper. Fitoterapia 80: 48-50, 2009.

33. Akgul T, Huri E, Ayyildiz A, et al. Haemostatic and Histopathological Effects of Ankaferd Blood Stopper, on Penile Cavernosal Tissue in Rats. UHOD 19: 159-165, 2009.

34. Ozaslan E, Purnak T, Ozyigit G, et al. No prolonged effect of Ankaferd Blood Stopper on chronic radiation proctitis. Endoscopy 42 Suppl 2: E271-272, 2010.

35. Ozaslan E, Purnak T, Yildiz A, et al. The effect of Ankaferd blood stopper on severe radiation colitis. Endoscopy 41 Suppl 2: E321-322, 2009.

36. Shorbagi A, Sivri B. Successful management of a difficult case of radiation proctopathy with Ankaferd BloodStopper: A novel indication (with video). Gastrointest Endosc 72: 666-667, 2010.

37. Huri E, Akgül KT, Yücel MÖ, Astarcı HM, Üstün H, Germiyanoğlu RC. The second step in vitro trial of Ankaferd $\AA$ Bloodstopper $\AA$ : comparison with other hemostatic agents. Turk J Med Sci 41: 7-15, 2011.

38. Aktaş A, Er N. Onur MA. Effects of Ankaferd Blood Stopper ${ }^{\circledR}$ on Vascular Response in Rat Carotid Artery. UHOD 20: 156-162, 2010.

39. Germiyanoğlu C, Hurı E, Akgül T, et al. Invivo Hemostatic Effect of Ankaferd Blood Stopper in Rat Major Renal Trauma Model: Controlled Trial of Novel Hemostatic Agent. UHOD 20: 206-211, 2010.

40. Ercetin S, Haznedaroğlu IC, Kurt M, et al. Safety and Efficacy of Ankaferd Blood Stopper in Dental Surgery. UHOD 20: 1-5, 2010.

41. Coban YK, Ozerol E, Tanber K, et al. The hemeostatic efficacy of ankaferd after excision of full thickness burns: a comparative experimental study in rats. Surgical Science 2: 16-21, 2011.

\section{Correspondence}

Dr. Murat ALBAYRAK

Yeni Etlik Cad. Meltem sok. Turkuvaz apt. No: 8/14

Etlik-Keçiören Ankara / TURKEY

Tel: (+90.505) 3900034

e-mail: muratalbayrak71@yahoo.com 